\title{
Adsorption equilibrium of lignite coal based activated carbon for dye removal
} \author{
Tebal, Penang, Malaysia \\ Penang, Malaysia

\section{Article Info

*Corresponding author:
Mohd Azmier Ahmad
School of Chemical Engineering
Engineering Campus, Universiti Sains
Malaysia
14300 Nibong Tebal
Penang, Malaysia
Tel: +6045996459
Fax: +604 5996908
E-mail: chazmier@usm.my

Murat $\mathrm{MN}^{1}$, Mohd Azmier Ahmad ${ }^{1,2 *}$ and Mohd Nazri Idris ${ }^{3}$

${ }^{1}$ School of Chemical Engineering, Engineering Campus, Universiti Sains Malaysia, 14300 Nibong Tebal, Penang, Malaysia

${ }^{2}$ Solid Waste Management Cluster, Science E Engineering Research Centre, Engineering Campus, Universiti Sains Malaysia, Nibong

${ }^{3}$ School of Materials and Mineral Resources Engineering, Engineering Campus, Universiti Sains Malaysia, 14300 Nibong Tebal,

Received: July 25, 2018

Accepted: August 22, 2018

Published: August 28, 2018

Citation: Murat MN, Ahmad MA, Idris MN. Adsorption equilibrium of lignite coal based activated carbon for dye removal. Int $J$ Petrochem Res. 2018; 2(2): 172-174.

doi: $10.18689 / \mathrm{ijpr}-1000130$

\begin{abstract}
Copyright: (c) 2018 The Author(s). This work is licensed under a Creative Commons Attribution 4.0 International License, which permits unrestricted use, distribution, and reproduction in any medium, provided the original work is properly cited.
\end{abstract}

Published by Madridge Publishers

\begin{abstract}
In this work, lignite coal based activated carbon (LCAC) was prepared by physicochemical activation for the removal of methylene blue (MB) dye from aqueous solution. The effects of dye initial concentration and contact time on $\mathrm{MB}$ adsorption were investigated. The LCAC has surface area and total pore volume of $750.7 \mathrm{~m}^{2} / \mathrm{g}$ and $0.511 \mathrm{~cm}^{3} / \mathrm{g}$, respectively. Result shows that the MB adsorption increases with initial MB concentration and contact time. Freundlich isotherm model fitted well the adsorption equilibrium data. The adsorption capacity of LCAC for MB adsorption was $245.1 \mathrm{mg} / \mathrm{g}$.
\end{abstract}

Keywords: Activated carbon, Adsorption, Lignite coal, Methylene blue

\section{Introduction}

Textile dyeing industries are facing challenges as it is one of the most chemically intensive industries in the world. This industry has been known as one of the major sources of water consumption as well as water pollution [1]. The primary function of water is to rinse the excessive dyes off from the colored and printed fabric. Water is also required for cleaning the printing machine to remove loose color paste from printing blankets, screens and dye vessels [2]. The dyeing process demands huge quantities of water for only small amount of dyed fabric with water to dye ratio is 15:1 [3]. Wastewater from dyeing process is often discharged into the lakes, rivers and other water resources causing water pollution. Dyes have chronic effect towards the exposed aquatic organisms, highly visible even in small concentration and not easily degradable by light, chemical and biological substances if not properly treated [4]. The adsorption technique so far is among the most versatile technique for dyes wastewater treatment. It has advantages such as high efficiency in removing dyes, low initial cost, easy to operate and simplicity of design [5]. Adsorbent particularly activated carbon (AC) has special characteristic such as high adsorption capacity and surface area which make it suitable to adsorb dyes. In this study, local Balingian lignite coal based activated carbon (LCAC) was used as adsorbent for removal of methylene blue (MB) dye from aqueous solution.

\section{Methodology}

The preparation of LCAC was conducted using the experimental setup shown in Figure 1. The equipment used consists of vertical tubular furnace having dimension of $500 \mathrm{~mm}$ long with $82 \mathrm{~mm}$ diameter with programmable controller (Model Carbolite, USA). A stainless-steel tubular cylinder with inner diameter of $25 \mathrm{~mm}$ and $150 \mathrm{~mm}$ long used for placing the sample was held in the center of the furnace. A wire mesh made of stainless steel is place at the bottom of cylinder to prevent the sample from falling out. 
The temperature within the sample bed in the reactor was measured by a $\mathrm{K}$-type thermocouple. The flue gas emitted from the reactor was condensed using a condenser at the bottom of the vertical tubular furnace.

The Balingian lignite coal was placed in tubular reactor and carbonized at temperature of $600^{\circ} \mathrm{C}$ for 1 hour under the nitrogen flow of $150 \mathrm{ml} / \mathrm{min}$ (purity=99.99\%) followed by activation with $\mathrm{CO}_{2}$ (purity $=99.99 \%$ ) gas at $900^{\circ} \mathrm{C}$ for 2 hours. Then, the reactor was cool to room temperature under nitrogen flow. This LCAC produced has high surface area and total pore volume of $750.7 \mathrm{~m}^{2} / \mathrm{g}$ and $0.511 \mathrm{~cm}^{3} / \mathrm{g}$, respectively.

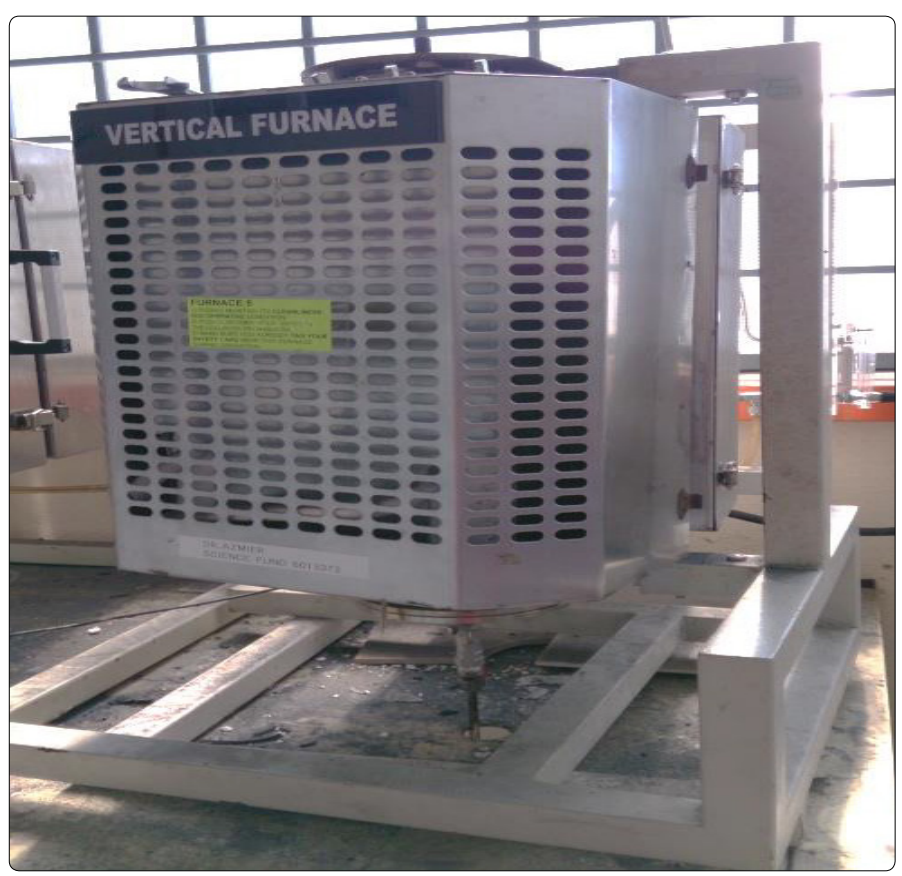

Figure 1. Stainless steel vertical tubular furnace

MB dye supplied by Sigma-Aldrich (M) Sdn Bhd, Malaysia was used as an adsorbate. Distilled water was used for preparing all solutions. Batch equilibrium tests were carried out for $M B$ adsorption on the LCAC prepared. The effects of MB initial concentration, contact time, and temperature on the adsorption uptake were investigated. The MB solutions were withdrawn at equilibrium to determine the residual concentrations. The $M B$ concentrations in the supernatant solutions before and after adsorption were determined using a double beam UV-Vis spectrophotometer (Shimadzu UV-1800, Japan) at its maximum wavelength of $668 \mathrm{~nm}$. The MB uptake at equilibrium was calculated by Eq. 1 .

$$
\mathrm{q}_{\mathrm{e}}=\frac{\left(\mathrm{C}_{0}-\mathrm{C}_{\mathrm{e}}\right) \mathrm{V}}{\mathrm{M}}
$$

where $C_{o}$ and $C_{e}(m g / L)$ are the liquid-phase concentrations of $\mathrm{MB}$ at initial and at equilibrium, respectively. $\mathrm{V}$ is the volume of the solution and $\mathrm{W}$ is the mass of dry adsorbent used.

\section{Results and discussion}

Figure 2 shows the effects of contact time and $M B$ initial concentration on the $\mathrm{MB}$ uptake on the $\mathrm{LCAC}$ at $30^{\circ} \mathrm{C}$. The plots show that the $\mathrm{MB}$ adsorption increased with time and reached a constant value beyond which no more MB was further removed from the solution. The amount of $\mathrm{MB}$ adsorbed at the equilibrium time reflected the maximum adsorption uptake of the LCAC. The MB adsorption was fast at the initial stages of the contact period, and thereafter it became slower near the equilibrium. This phenomenon was due to the large number of vacant surface sites were available for adsorption during the initial stage [6]. After a lapse of time, the remaining vacant surface sites were difficult to be occupied due to repulsive forces between the solute molecules on the solid and bulk phases [7].

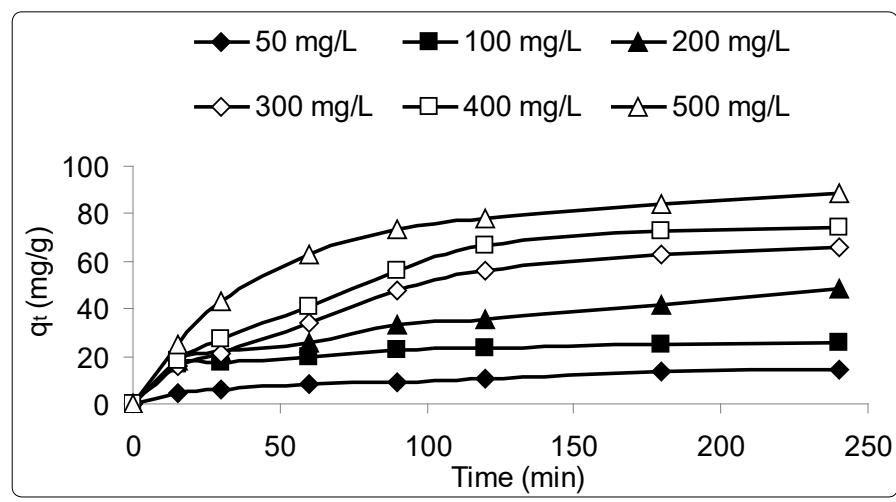

Figure 2. MB adsorption on LCAC at various initial concentrations.

The adsorption isotherm indicates how the adsorption molecules distribute between the liquid phase and the solid phase when the adsorption process reaches an equilibrium state. The analysis of the isotherm data by fitting them to different isotherm models is an important step to find the suitable model that can be used for design purpose. The isotherm data were fitted to the Langmuir, Freundlich and Temkin isotherms. The Langmuir isotherm is represented by the following linear equation [4]:

$$
\frac{C_{e}}{q_{e}}=\frac{1}{K_{L} q_{m}}+\frac{1}{q_{m}} C_{e}
$$

where $C_{e}(\mathrm{mg} / \mathrm{L})$ is the equilibrium concentration, $q_{e}$ $(\mathrm{mg} / \mathrm{g})$ the amount of adsorbate adsorbed per unit mass of adsorbate, and $\mathrm{q}_{m}$ and $\mathrm{K}_{L}$ are the Langmuir constants related to adsorption capacity and rate of adsorption, respectively. When $C_{\mathrm{e}} / q_{\mathrm{e}}$ was plotted against $C_{\mathrm{e}^{\prime}}$ straight line with slope $1 / \mathrm{q}_{\mathrm{m}}$ was obtained. The Langmuir constants $\mathrm{K}_{\mathrm{L}}$ and $\mathrm{q}_{\mathrm{m}}$ were calculated from this isotherm and their values are listed in Table 1.

The linear form of the Freundlich equation is [9]:

$$
\ln q_{e}=\ln K_{F}+\frac{1}{n} \ln C_{e}
$$

where $q_{\mathrm{e}}$ is the amount adsorbed at equilibrium $(\mathrm{mg} / \mathrm{g})$ and $C_{\mathrm{e}}$ is the equilibrium concentration of the MB. $K_{\mathrm{F}}$ and $n$ are Freundlich constants, $n$ giving an indication of how favorable the adsorption process and $K_{\mathrm{F}}\left(\mathrm{mg} / \mathrm{g}(\mathrm{L} / \mathrm{mg})^{1 / n}\right)$ is the adsorption capacity of the adsorbent. The plot of $\ln q_{\mathrm{e}}$ versus $\ln C_{e}$ gives straight lines with slope $1 / n$. Freundlich constants $\left(K_{\mathrm{F}}\right.$ and $\left.n\right)$ were calculated and listed in Table 1.

Temkin isotherm is represented by the following equation [10]:

$$
q_{e}=\left(\frac{R T}{b}\right) \ln \left(A_{t} C_{e}\right)
$$

Equation 4 can be expressed in its linear form as

$$
q_{e}=B \ln A+B \ln C_{e}
$$

where $B=R T / b$ 
A plot of $q_{\mathrm{e}}$ versus $\ln C_{\mathrm{e}}$ enables the determination of the isotherm constants $A_{t}$ and $\mathrm{B}$. $A_{t}$ is the equilibrium binding constant $(\mathrm{L} / \mathrm{mg})$ corresponding to the maximum binding energy and constant $B$ is related to the heat of adsorption. The values of the parameters are given in Table 1.

Based on the $\mathrm{R}^{2}$, Freundlich isotherm seemed to represent the equilibrium adsorption data with better fit as compared to the other isotherms. This explains the heterogeneous nature of the LCAC surface [5]. The value of $n$ was greater than unity, suggesting that MG dye was favorably adsorbed by LCAC.

Table 1. Isotherm parameters for MB adsorption by LCAC at different temperatures

\begin{tabular}{|c|c|c|c|c|c|c|c|c|c|c|}
\hline \multicolumn{5}{|c|}{ Langmuir } & \multicolumn{3}{|c|}{ Freundlich } & \multicolumn{3}{|c|}{ Temkin } \\
\hline $\begin{array}{c}\text { Temp } \\
\left({ }^{\circ} \mathrm{C}\right)\end{array}$ & $\begin{array}{c}\mathrm{q}_{\mathrm{m}} \\
(\mathrm{mg} / \mathrm{g})\end{array}$ & $\begin{array}{c}\mathrm{K}_{\mathrm{L}} \\
(\mathrm{L} / \mathrm{mg})\end{array}$ & $\mathrm{R}^{2}$ & $\mathrm{R}_{\mathrm{L}}$ & $\mathrm{n}$ & $\begin{array}{c}\mathrm{K}_{\mathrm{F}} \\
(\mathrm{mg} / \mathrm{g}(\mathrm{L} / \\
\left.\mathrm{mg})^{1 / \mathrm{n}}\right)\end{array}$ & $\mathrm{R}^{2}$ & $\begin{array}{c}A_{t} \\
(L / m g)\end{array}$ & B & $\mathrm{R}^{2}$ \\
\hline 30 & 245. & 0.00 & 3 & 0.542 & 1.34 & 0.992 & 0.991 & 0.037 & 30.5 & 0.973 \\
\hline 50 & 224.4 & 0.002 & 0.947 & 0.936 & 1.35 & 1.142 & 0.992 & 0.039 & 31.7 & 0.977 \\
\hline 70 & 168.1 & 0.0032 & 0.903 & 0.911 & 1.42 & 2.279 & 0.981 & 0.051 & 29.8 & 0.950 \\
\hline
\end{tabular}

\section{Conclusion}

The present investigation showed that LCAC was an effective adsorbent for the $M B$ adsorption from aqueous solution. $M B$ adsorption of was found to increase with increase in contact time and initial dye concentration. Isotherm study of MB onto LCAC was best fitted by Freundlich isotherm model which indicated multilayer adsorption process occurred on heterogeneous surfaces.

\section{Acknowledgements}

The authors are grateful for the funding from Solid Waste Management Cluster (RU 1001/CKT/870023) and Bridging Grant of Universiti Sains Malaysia.

\section{References}

1. Khelifi E, Bouallagui $H$, Touhami $Y$, Godon JJ, Hamdi M. Bacterial monitoring by molecular tools of a continuous stirred tank reactor treating textile wastewater. Bioresource Technology. 2009; 100(2): 629-633. doi: 10.1016/j. biortech.2008.07.017

2. Kant R. Textile dyeing industry an environmental hazard. Natural Science. 2012; 4: 22-26. doi: 0.4236/ns.2012.41004

3. Nethaji $S$, Sivasamy A. Adsorptive removal of an acid dye by lignocellulosic waste biomass activated carbon: Equilibrium and kinetic studies. Chemosphere. 2011; 82(10): 1367-1372. doi: 10.1016/j.chemosphere.2010.11.080

4. Heibati B, Rodriguez-Couto S, Amrane A, Rafatullah M, Hawari A, et al. Uptake of Reactive Black 5 by pumice and walnut activated carbon: Chemistry and adsorption mechanisms. Journal of Industrial and Engineering Chemistry. 2014; 20(5): 2939-2947. doi: 10.1016/j.jiec.2013.10.063

5. Ahmad MA, Afandi NS, Adegoke KA, Bello OS. Optimization and batch studies on adsorption of malachite green dye using rambutan seed activated carbon. Desalination and Water Treatment. 2015; 57(45): 2148721511. doi: 10.1080/19443994.2015.1119744

6. Zhou L, Yu Q, Cui Y, Xie F, Li W, et al. Adsorption properties of activated carbon from reed with a high adsorption capacity. Ecological Engineering. 2017; 102: 443-450. doi: 10.1016/j.ecoleng.2017.02.036

7. Shamsuddin MS, Yusoff NRN, Sulaiman MA. Synthesis and characterization of activated carbon produced from kenaf core fiber using $\mathrm{H}_{3} \mathrm{PO}_{4}$ Activation. Procedia Chemistry. 2016; 19: 558-565. doi: 10.1016/j.proche.2016.03.053

8. Langmuir I. The adsorption of gases on plane surfaces of glass, mica and platinum. Journal of the American Chemistry Society. 1918; 40(9): 13611403. doi: $10.1021 / \mathrm{ja} 02242 \mathrm{a} 004$

9. Freundlich HMF. Over the adsorption in solution. Journal of Physical Chemistry. 1906; 57: 385-470.

10. Tempkin MJ, Pyzhev V. Recent Modifications to Langmuir Isotherms. Acta Physiochim. USSR, 1940; 12: 217-222. 